\title{
Beslenme Odağında Sağlık Krizi
}

\section{Health Crisis in the Focus of Nutrition}

\section{Esra KARAKUŞ UMAR *}

Öz: Sağlık ve beslenme, birbirinden ayrılamayacak iki kavramdır. Sağlığın bozulmasına ya da sağlıklı olmaya neden olarak gösterilen beslenme, günümüzde sorgulanır hale gelmiştir. Beslenmenin sağlıklı olmak adına bireyler tarafından kullanılması, farklı tüketim odaklarının da dikkatini çekmiştir. Bu çalışmada da sağlıklı olmak adına beslenmenin, riskler ve korkular yoluyla araçsallaştırılması ve tüketim kültürüne hizmeti incelenmiştir. Görüşmeler, Kütahya'nın Tavşanlı ilçesinde tarım yapan ve yapmayan elli bir görüşmeci ile gerçekleştirilmiştir. Görüşmeciler, genç ve yetişkin görüşmeciler olmak üzere ikiye ayrılmıştır. Genç görüşmecilerin sağlık tanımları, yetişkin görüşmecilerin sağlık tanımlarından farklılaşmıştır. Görüşmecilerin, risklerden kaçınma fikrine sahip oldukları ancak risk içeren gıdaları tükettikleri görülmüştür. Görüşmeciler, hazır gıdaların sağlıksız olduğunu düşünmelerine rağmen, zaman kazandırması ve kolaylık sağlaması adına hazır gıdaları tüketmektedirler. Görüşmecilerin; şişmanlama, ölüm ve hastalanma korkusuna sahip oldukları görülmüştür. Görüşmeciler, korkularıyla başa çıkmak adına bilgi sahibi olma yolunu tercih etmektedirler. Bu durum onları, tüketime yönlendirmektedir. Görüşmeciler; sağlık bilgisinin, uzmanlarının ve kurumlarının tüketicisi durumundadırlar. Genel anlamda bilginin yarattığı anomi, görüşmecilerin uzmanlara karşı güvensiz hissetmesine neden olmuştur.

Anahtar sözcükler: Beslenme, Sağlık, Tüketim, Risk, Korku

Abstract: Health and nutrition are two concepts that cannot be separated. The diet, which has been shown to cause health deterioration or health, has become questionable today. The use of nutrition by individuals in order to be healthy has attracted the attention of different consumption centers. In this study, in order to be healthy, the instrumentalization of nutrition by means of risks and fears and service of consumer culture are examined. The interviews were carried out with fifty interviewees who did not produce and produce in Tavşanl, Kütahya. Interviewees are divided into young and adult interviewees. The health definitions of the young interviewees differed from the health definitions of the adult interviewers. It was observed that the interviewees had the idea of avoiding risks but they consumed risky foods. Interviewers consume ready-to-eat foods to save time and provide convenience, although they think that food prepared in this way is unhealthy. Interviewees were found to have fears of obesity, death and sickness. The interviewees prefer to have knowledge to deal with their fears. This leads them to consumption. The interviewees are consumers of health information, experts and institutions. In general terms, the information created by the anomi, caused the interviewees to feel insecure about the experts.

Keywords: Nutrition, Health, Consumption, Risk, Fear

\footnotetext{
* Dr. Öğr. Ü., Atatürk Üniversitesi, Oltu Beşeri ve Sosyal Bilimler Fakültesi, Sosyal Hizmet Bölümü, Erzurum. esra.umar@atauni.edu.tr, https://orcid.org/0000-0003-1764-9394

Bu makale, Esra Karakuş Umar'ın doktora tezinden yararlanılarak hazırlanmıştır.
} 
Giriş

Küreselleşen dünyada beslenme, sağlıklı olmanın aracı iken hastalıkların da nedeni olarak gösterilmektedir. Besin maddelerinin sorgulandığ 1 bu dönemde beslenmenin sorunsallaştırılmasının geri planında farklı tüketim odaklarının olduğu dikkat çekmektedir. Bireylerin tüketim kültürüne hizmet etmesi ise beslenmenin çevresinin sarıldığı riskler ve korkularla sağlanmaktadır. Bu çalışmada da sağlıklı olmak adına beslenmenin, riskler ve korkular yoluyla araçsallaştırılması ve tüketim kültürüne hizmetinin sosyal alanda nasıl inşa edildiği sorgulanmıştır.

$\mathrm{Bu}$ çerçevede araştırmada, 18-65 yaş arası elli bir görüşmeci ile derinlemesine mülakatlar gerçekleştirilmiştir. Görüşmecilerin genç ve yetişkin şeklinde ayrılmasına özen gösterilmiş ve sağlık anlayışındaki geçmiş ve şimdiki deneyimlerine odaklanılarak sağl $\breve{g}_{1}$, beslenme üzerinden inşa süreçleri irdelenmiştir. Derinlemesine mülakatlar, açık uçlu sorularla ve yarı yapılandırılmış formlarla yürütülmüş, gerekli görülen yerlerde alana geri dönüşlerle temalar hakkında derinlik sağlanması amaçlanmıştır.

Ayrıca sağlık için beslenme üzerinden inşa edilen tüketim kültürünün, risk ve korku olgusu üzerinden inşası incelenirken "kriz" kavramının kullanılmasının sebebi, bilgi toplumunda yaşamanın yarattığı "anomi”" durumudur. Öyle ki bu anomi durumu bireylerin, bilgiye ulaşması sıkıntısının aksine ulaşılan bilginin içeriği ile alakalıdır. Bilginin bolluğu, bireylerin sağlı̆̆ını koruyacak ya da sağlıklı olmalarını sağlayacak bir durum yerine sürekli tüketmelerini sağlamak adına yeniliklerden haberdar olmaları ve satın almalarını yönlendiren bir konu halini almıştır.

Sağlık anlayışı, içinde bulunulan dönemin özelliklerini yansıtır. Neticede sağlık üzerinde bedensel, sosyal, psikolojik, ekonomik ve tarihsel pek çok süreç etkili olmaktadır. Bu bağlamda geleneksel toplum yapısının hakim olduğu bir coğrafyadaki sağlık anlayışında da geleneksel öğelerin kullanıldığ 1 görülmektedir. Örneğin Mezopotamya uygarlığı sağl1klı olmayı, ruhun rahatta olması ve bireyin tanrı ile bağlantısının iyi olması şeklinde yorumlarken burada affedilme üzerinden inşa edilmiş bir tedavi süreci söz konusudur (Aydın 1997, 1-5).

Sağlık anlayışları sadece bir kültürün değil o coğrafya ile etkileşimde bulunan kültürlerden de izler taşımaktadır. Bu durum sağlık anlayışının bir kültür öğesi olarak çok kültürlü bir yapıya sahip olabileceğini de göstermektedir. Türkiye'deki geleneksel sağlık anlayışı, Osmanlı'nın izlerini taşımaktadır. Osmanlı mutfağı, beslenme ile sağlık arasında özel bir ilişki kurmaktadır. Sağlıklı olmanın bitkilerin şifalarından yararlanmaktan geçtiğini öne süren aşçılar, tıp eğitimi de almış hekimlerdir (Akkor 2013). Aynı zamanda Türkiye'deki mevcut sağlık anlayışında dinin izleri de görülmektedir (Tunaboylu 1995). Örnek olarak "oruç tutmak" her ne kadar İslami bir temelden yükselen davranış biçimi olsa da oruç tutarken beslenme ile sağlık arasında ilișki kurulmaktadır. Kur'an-1 Kerim'in değindiği sağlık sorunları ve Hz. Muhammed'in sağlıkla ilgili hadisleri Türkiye'deki sağlık anlayışına kaynaklık etmektedir (Demirhan 1982).

Küreselleşmenin etkisiyle diğer kültürel öğelerde ortaya çıkan benzeşme sağlık anlayışında da ortaya çıkmıştır. Yerel sağlık anlayışının yanında modern sağlık anlayışı, tüm kültürlerin üzerinde ekonomik bir sürecin sonucu olarak değerlendirilebilir. Öyle ki küreselleşme, modern sağlık anlayışının tüketim kültürüne hizmet etmesine aracı olabilmektedir. Bireylerin tüketime yönlendirilmesi özellikle de sağlık söz konusu olduğunda zor olmamış risklerin ve korkuların yaratılması ile süreç daha da karmaşıklaşmıştır.

\section{Sağlık Krizinin Temeli}

Bugün tüm dünyada sağlık krizinin yaşandığını söylemek için erken değildir. Sağlık krizi; sağlık kurumları, sağlık uzmanlarıyla ilgili olabildiği gibi çalışmada da yer aldığı şekilde sağlık iletişiminde ve sağlık hakkındaki bilgide de ortaya çıkmaktadır. Burada "kriz" kavramı ile anlatılmak istenen ise bireyin sağlığı ile alakalı olarak içinde bulunduğu bunalım durumudur. 
Öyle ki birey, sağlığı hakkında kendi karar verir durumdadır ancak sağlığını bozan nedenlerden de bağımsızdır ve söz konusu nedenlere bireysel olarak müdahale edememekte ve kendini de koruyamamaktadır.

Sağlık krizi, beslenme özelinde incelendiğinde hem gıdaya ulaşımda sıkıntı yaşanmakta hem de gıdanın aşırı tüketimi şeklinde kendini göstermektedir. Bu iki durumun yanında bir de gıdaya ulaşmış olunmasına rağmen gıdanın içeriğine ilişkin yaratılan soru işaretleri, gıdaya yaklaşımda sorun yaratmaktadır.

Gıda güvencesi kavramı, Birleşmiş Milletler Gıda ve Tarım örgütü tarafından "bütün insanların her zaman aktif ve sağlıklı bir yaşam için gerekli olan besin ihtiyaçlarını ve gıda önceliklerini karşılayabilmek amacıyla yeterli, sağllkll, güvenilir ve besleyici gıdaya fiziksel ve ekonomik bakımdan sürekli erişebilmeleri" șeklinde tanımlanmıştır (Koç 2013, 15). Türkiye'de gıda güvencesini tartışan Niyaz ve İnan (2016), çalışmalarında Türkiye'de gıda güvencesinin sağlanamadığı sonucuna varmışlardır. TÜİK verilerine göre Türkiye'de yeterli miktarda gıdaya ulaşamayan insan sayısı 13 milyon civarındadır (evrensel.net). Dünyada ise "6,2 milyar insandan 826 milyonu sürekli yetersiz beslenmekte ve kronik açlık çekmektedir" (Arpacioğlu \& Yildırım 2011, 65).

Gıdaya ulaşamayan kesimin yanında gıdaya ulaşmasına rağmen gıdanın, bazı kriterlere uymaması durumu da yetersiz olarak değerlendirilmektedir. Gıdaya ulaşan nüfus, gıdanın içeriği hakkında daha çok bilgi sahibi olmak istemektedir. Gıda güvenliği olarak kavramsallaştırılan bu durum "gıdaların, tarladan sofraya kadar olan zincirini kapsamaktadır. Gıdaların üretim, işleme, saklama, taşıma ve dağıtım aşamalarının uygun şartlarda yapılmasıdır" (Onurlubaş \& Gürler 2016, 133). Gıda güvenliğinin sağlanması için gıdanın kalitesinin ölçülebileceği kalite güvence sistemlerine ilişkin çalışmalar yapılmıştır. Söz konusu kalite sistemlerinin amacı, sağlığa risk oluşturan içeriklere sahip olması sebebiyle üretilen gıdaların yok edilmesi durumunu en başından engelleyerek sağlıklı içeriğe sahip gıdaların üretiminin sağlanmasıdır.

Gıda güvenliğinin sağlanması, besinleri üreten üretici ve besinleri satanlarla ilgili bir durum olmasına rağmen söz konusu besinlerin tüketilmesi, bireyin sorumluluğundadır. Örneğin domatesin hormonlu olduğunun bilerek tüketilmesi, hastalıklara davetiye çıkarır gözüyle bakılırken; hamburger yemenin kanser riskini artırdığı ve tüketilmemesi gerektiğinin, bireyin bilmesi gereken bir bilgi gibi sunulduğu görülmektedir. O halde birey, tüketecek gida bulamaması durumunda sağlık riski ile karşı karşıyadır. Ancak tüketecek gıda bulması durumunda da besinin içeriği ve özelliği ile ilgili belirsizliklerden dolayı sağlık riski ile karşı karşıyadır.

\section{Beslenme ve Tüketim Kültürü ilişkisi}

Beslenme, bireyin hayatta kalmak için yerine getirmesi gereken zorunlu bir ihtiyacıdır. Fakat beslenmenin tüketim kültürüne hizmet etmesi, değerlendirilmesi gereken bir durumdur. Beslenme ve tüketim kültürü ilişkisi sağlık özelinde incelendiğinde; beslenme ile hastalıklardan korunmak ya da ortaya çıkan hastalıkla mücadele etme yöntemlerinden biri olarak değerlendirilebilir. "Beslenme, sürekli yeni bilgilerle bireyin takip etmesi gereken bir kültür haline gelmiştir. Böylelikle tüketim kültürü, beslenme vasıtasıyla gündelik hayatın bir parçası haline gelmiştir” (Karakuş-Umar 2019).

Tüketim kültürü, özü itibariyle Baudrillard (2010)'ın da dediği gibi peşinde koşulan arzuların dindirilmesi ve yerine yeniden bir arzunun oluşmasını temsil etmektedir. Sağlık ile tüketim kültürü ilişkisini beslenme üzerinden kuran çalışmalarda "Sağllklı olma kültürü" (healthism) olarak isimlendirilen bu durum, "săgllklı olma" imgesinin tüketilmesini ifade etmektedir. "Sağllklı olma" imgesi, sağlıklı olmak için sunulan yapıp etmeler ve tüketim nesnelerine sahip olmayı ifade etmektedir. Neticede günümüzde sağliklı olmak, belirli besinlerin ne olduğunun sürekli değiştiği bilgi durumunun ifadesidir. 
Tüketim kültürünün kendine sağlığı, tüketilebilecek bir alan olarak seçtiği ve bunu da beslenme üzerinden sağladığı fikrinin uygulama alanlarından birisi; organik gıda endüstrisidir. Organik gıda endüstrisi, sağlıklı ürün üretimi ile bireyleri hastalıktan koruduğunu iddia etmektedir. Bunu da yüksek ücretli ürünleri ile sağlamaktadırlar. Ayrıca beslenme üzerinden inşa edilen tüketim kültürü öğelerinin geleneksel ürünler olduğu söylenebilir. Geleneksel ürünler, modern üretim teknolojilerinden etkilenmeden geleneksel tarzda üretimin yapıldığı sürecin sonucu olarak düşünülebilir.

Modern üretim teknolojileri; genetiği değiştirilmiş ürünler, yapay tatlandırıcılar ya da hazır gıdalar vb. şeklinde örneklendirilebilir. Modern üretim teknolojilerinin yarattığı riskler ise küresel riskler olarak düşünülmektedir. Küresel riskler, geleneksel dönem risklerinden daha geniş alana yayılması özelliği ile ayrılmaktadırlar (Soydemir 2011, 171). Dolayısıyla insan sağlı̆̆ını küresel anlamda tehdit eden riskler, yarattığı korku ortamıyla birlikte bireyleri tüketim fikrine yönlendirmektedir.

\section{Risk ve Korku Olgusunun Tüketim Kültürü İle İlişkisi}

Günümüzde riskler, özellikle beslenme söz konusu olduğunda gönüllü riskler olarak değerlendirilmektedir. Gönüllü riskler kavramı ile anlatılmak istenen bireylerin, besinlerin zararlı olduğunu bilerek tüketmeye devam etmeleridir. Beck (2014), risklerin gönüllü ya da gönülsüz olmasına bakılmaksızın tüm bireyleri etkilediğinden yani "riskin demokratikleşmesi” durumunun ortaya çıktığından bahsetmektedir. Riskler, tüm insanlığı etkiler durumdadır. Ayrıca sadece bir ülkeyi etkilemekle kalmayıp, oluştuğu ortamdan bağımsızlaşarak ve küreselleşerek tüm dünya ülkelerini tehdit etmektedir.

Yine riskler gibi korku konusunda da farklılaşma söz konusudur. Dieter Duhm (2009, 4751) doğal korkuların farklılaşarak yapay korkular halini aldığından söz etmektedir. Yani korkular, doğa ile karşı karşıya gelen bireyin, bilinmezle yüzleşmesinden daha fazlasını ifade etmektedir. Sonradan ortaya atılmış korku kaynakları, toplumsallaşma süreciyle öğrenilmekte ve bireylerin hayatlarını şekillendirmektedir. Böylelikle birey, sürekli huzursuz bir şekilde korkularına çare arar vaziyettedir (Duhm 2009, 173). Furedi (2014, 8-11) günümüzde tüm güvenlik önlemleri alınmasına rağmen neden herkesin kendisini korku dolu hissettiğini anlamaya çalışır. "Gerçek ve sanal arasındaki sınırların belirsizleşmesi”, bireylerin kendilerini güvensiz hissetmelerine neden olmaktadır. Buradaki sanal kelimesinin anlamı, ortaya çıkmamış ancak bir risk gibi bahsedilen durumların dile getirilmesi olarak düşünülebilir. Örneğin Furedi $(2014,16)$ 'nin mangal keyfinin hayatımızı nasıl tehdit eden unsurlar içerdiğine ilişkin uyarı örneği ele alınabilir. Dahası el sıkışırken, elinizi sıkan kişiden beşte birinin tuvaletten çıktıktan sonra ellerini yıkamadığına ilişkin elde edilen bilginin toplumla paylaşılması ve uyarı niteliği taşıması "sanal ile gerçek olan" ayrımının ortadan kalktı̆̆ına örnektir.

Riskler ve korkular; bilginin çoğalması ve yayılması ile ilgilidir. Bireyler, bilginin yayılması ile riskler hakkında daha çok bilgiye sahip olmak isterken daha çok korku sahibi olmaktadırlar. $\mathrm{Bu}$ da korkularla başa çıkma yolu olarak tüketimi seçmelerine neden olabilmektedir. Bunun için sağlığa ilişkin haberi ve bilgiyi, sağlık kurumlarını, sağlık uzmanlarını ve sağlık ürünlerini tüketirler. Bu durum "gündelik yaşamın profesyonelleşmesi" şeklinde kavramsallaştırılmıştır (Furedi 2014, 188). Birey, sağlık konusunu ilgilendiren her noktaya hakim olmaya çalışmaktadır. Bu da onun gündelik hayatının her alanına ait bilgiyle donanımlı olması anlamına gelmektedir.

Netice itibariyle, bilginin hızla çoğalması ve yayılması, bireylerin daha çok tüketimine neden olmaktadır. Bunun da sebebi, günümüz politikalarıdır. Neoliberal politikaların etkisi ile ekonominin tüm alanları belirlemesi, sağlık alanında da kendini göstermektedir. Bireyler, kendi sorunlarıyla kendileri başa çıkmaya çalışmaktadır. Neoliberal politikaların özgürleşen bireyler olarak düşündüğü neoliberal birey, bireyselleştirilen sağlık problemleri ile sadece tüketerek başa 
çıkabilmeye çalışmaktadır. Marcuse (1997) "aldatıcı özgürlükler" olarak tanımladığı tüketme durumunu, bireyin seçim yapma hissine kapılması şeklinde tanımlamaktadır.

\section{Araştırmanın Metodu}

Sosyolojik bir araştırmada seçilen yöntem, araştırmacının konuya yaklaşımının bir sonucudur. Eleştirel yaklaşımın seçildiği çalışmada, seçilen nitel yöntemle birlikte araştırma deseni, baştan aşağıya şekil almaktadır. Nitel araştırmalar, konu hakkında derinlemesine bilgi sağlamasıyla önem taşırlar ve diğer araştırma tekniklerinden ayrılırlar. Bu anlamda çalışmada da nitel araştırma yöntemi kullanılmıştır. Çalışmada "neden" ve "nasıl" sorularına odaklanma maksadıyla nitel araştırma tekniklerinden derinlemesine görüşme tekniği kullanılmıştır.

Araştırmada nitel araştırma tekniğinin seçimi, araştırmanın konusuyla ve amacıyla doğru orantılıdır. Araştırmanın konusu olan "sağllğın beslenme ile tüketim kültürüne hizmet etmesi" sorgulanırken nitel araştırma yönteminin vereceği derinleşme imkanı, araştırmanın amacı olan "risklerin ve korkuların beslenmenin araçsallaştırılmasındaki rolünün ortaya çıkarılması" fikrinin de incelenmesine olanak sağlayacaktır. Beslenmenin araçsallaştırılması ifadesi ile anlatılmak istenen, beslenmenin tüketim kültürüne hizmetinin geri planında yatan, sağlıklı olma vaadidir. Araştırmada üzerinde durulan ilk tema beslenmenin araçsallaştırmasıdır. Böylelikle sağl1ğın anlamındaki değişimin ortaya çıkarılması, nitel araştırma yönteminin işaret ettiği derinlemesine görüşmelerle sağlanacaktır.

Görüşmecilerin seçiminde olasıllğa dayalı olmayan, amaçlı örneklem tekniği kullanılmıştır. Kütahya ili Tavşanlı ilçesinde ikamet eden 18-65 yaş arasındaki kadın ve erkek görüşmecilerin evli olmasına dikkat edilmiştir. Görüşmecilerin evli olmasına dikkat edilmesinin sebebi ise belirli bir beslenme rutinine sahip olmaları özelliğidir. Görüşmecilerde beslenme ve tüketim ilişkisine bakışın farklılığını anlamak adına 40 yaş üstü görüşmeciler, "yetişkin" olarak belirlenmiştir. 18-39 yaş arasındaki görüşmeciler de "genç" görüşmeci olarak isimlendirilmiştir. Ayrıca cinsiyetin, tüketim kültürü için bir ayrım yaratmaması, araştırmada da cinsiyet ayrımına gidilmemesine neden olmuştur. Baudrillard (2010)'ın da değindiği gibi tüketim kültürü için kadın ya da erkek fark etmeden bireyin tüketiciliği önemlidir.

Şubat 2017'den Ekim 2017'ye kadar gerçekleştirilen görüşmelerde elli bir kişi ile derinlemesine mülakatlar gerçekleştirilmiştir. Derinlemesine görüşmeler, yüz yüze gerçekleştirilmiştir. Görüşmelerin kayıt altına alınması adına ses kayıt cihazı kullanılmıştır. Bazı görüşmeciler, ülkedeki olağanüstü hali sebep göstererek görüşmenin kayıt altına alınmasını istemediklerini belirtmiş̧lerdir. Araştırmanın konusu ve kapsamı hakkında bilgilendirme yapılmasına rağmen ikna olmayan görüşmecilerle yapılan görüşmelerde "elle not alma" tercih edilmiştir.

Görüşmelerde, açık uçlu sorularla derinleşmeyi gerçekleştirmek maksadıyla yarı yapıland1rılmış görüşme formu kullanılmıştır. Görüşmeler sırasında dört ana başlık altındaki sorularda derinleşmeye özen gösterilmiştir. Görüşmeci anlatılarının yeterli olmadığı noktalarda yeni alt sorular eklenerek yeni görüşmecilerle görüşmeler gerçekleştirilmiştir. Görüşmeler sırasında sadece sorular dikkate alınmamıştır. Görüşmecilerin davranışları da gözlemlenmiştir. Böylelikle görüşmecinin görüşme sürecinden kopmaması ve konudan uzaklaşmamasının sağlanmasına dikkat edilmiştir.

Veriler, sistematik şekilde tanımlanması açısından nitel veri analiz tekniklerinden, içerik analizi ile çözümlenmiştir. İçerik analizi, temalar üzerinden üretildiğinden araştırmada da "sağllğın anlamındaki değişim ve beslenmenin yeri", "tüketim kültüründe beslenme ve sağllk ilişkisi" ile "beslenmeye ilişkin korku ve riskler" temaları üzerinden hareket edilmiştir. Söz konusu temalar alt temalar ile detaylandırılmıştır. Sağlığın anlamındaki değişimin görülmesi maksadıyla ilk olarak sağlığın geçmişteki görünümü incelenmiştir. 


\section{Sağlıklı olmak ve Beslenme ilişkisinin Geçmişteki Görünümü}

Sağlığın anlamındaki değişimin ortaya çıkabilmesi için genç ve yetişkin görüşmecilerin geçmiş beslenme deneyimlerinden yola çıkılmıştır. Bireyin ürettiğini tükettiği dönemde sağlıklı olmak ile besinin içeriği arasında ilişki kurulmamasını, yetişkin görüşmecilerin sözlerinde somutlamak mümkündür.

...Eskiden öyle bir kaygıları yoktu insanların. Ne bulurlarsa o gün onlarla karınlarını doyuruyorlardı. Bugün mesela kalkayım da özel olarak şu ottan şu yemeği yapayım da bu çok sağllklıdır. O gün neyse önlerine gelen pişirmeleri gereken onu yapıp onu yiyorlardl. O tabi ki o günkü imkânların da verdiği bir şey sonuçta. Belki imkânları o kadar olduğu için... (G14-Kadın, 56).

Genç görüşmeciler, geçmişteki beslenme alışkanlıklarını, maddi koşullar ile ilişkili olarak değerlendirmektedir. Söz konusu dönemde bireyler, ürettikleri ile yetinmeyip daha fazla gelir elde etme yoluna gitmişlerdir. Böylelikle bir anlamda yetişkin görüşmeciler ile genç görüşmeciler arasındaki dönemde besin çeşitliliğinin arttı̆̆ söylenebilir. Fakat bu dönemde sağlık için değil maddi imkânların el verdiği şekilde besinler satın alınmaktadır.

Biz ürettiğimizi tüketirken zengin olan ya da imkânı olanlar köyde yaşamak yerine başka yerlere göç ediyorlardl. Büyük şehirlere gidiyorlardl. Onlar, üretmekten çok dışarıdan alıyorlardl yiyeceklerini zaten göç ettikleri yerler de ya şehir ya da yurt dışı oluyordu. Yani üretecekleri değil daha rahat harcayabilecekleri yerlere göç ediyorlardı (G19Erkek, 28).

Sağlıklı olmak, yetişkin görüşmecilerin geçmiş anlatılarında olağan bir durum olarak görülmektedir. Herkes sağlıklı olduğundan, yetişkin görüşmecilerin anlatılarında hasta olup hastaneye gittiğini hatırlamayan görüşmeciler mevcuttur.

"Kim doktora gidecekti o zaman. Doktora gitmek eziyetti. Zaten küçügüz babam götürmek isterse götürürdü. Ama ben ne hasta olduğumu ne de babamın beni hastaneye götürdüğ̈̈nü hatırlamıyorum" (G23-Erkek, 43).

Geçmiş anlatılarında genç görüşmeciler, hasta olduklarını ve sıklıkla hastaneye gittiklerini belirtmişlerdir. $\mathrm{Bu}$ durum sağlık konusunda, yetişkin ve genç görüşmeciler arasında farklılık olduğunu göstermektedir.

"Devlet hastanesi evimize yakın olduğu için hemen doktora giderdik.

Doktor iğne verirse evimize daha yakın olan hastaneye vurdururduk"

(G3-Erkek, 27).

İyileşme açısından çorbanın hem genç hem de yetişkin görüşmeciler için önemli olduğu görülmüştür. Yetişkin görüşmeciler çorbayı, tek iyileşme aracı olarak görürken genç görüşmecilerin çaresiz kaldıklarında başvurdukları bir yöntem olarak çorba içmektedirler.

"Hasta olup okuldan eve gönderilmiştim. Annem, beni alıp hastaneye götüremezdi. O sebeple hemen çorba yapardı" (G21-Kadın, 29).

Yetişkin görüşmeciler, çorbanın iyileştirici gücünden bahsederken genel anlamda zaten hastalıkların olduğu bir ortamda yaşamadıklarını da belirtmişlerdir. Bunun için geçmişte hastalıklardan korunma anlayışının yetişkin görüşmecilerde olmadığ 1 görülmüştür. Yetişkinlere göre sebebi, doğal, mevsiminde ve kendi ürettiklerini tüketmeleridir. 
"Kışın yenilebilecek ve üretilen şeyleri kışın yerdik. Yazın yiyeceğimiz şeyleri yani domates gibi şeyleri yazın yerdik. Her şeyi mevsiminde yerdik. Ben bundan dolayı korunmanın gereği olmadı̆̆ını düşünüyorum” (G25-Erkek,48).

Genç görüşmecilerin geçmişlerinde hastalık deneyimleri olduğu ancak son yıllarda hastalıkların daha çok arttığına ilişkin düşünceleri dikkat çekicidir. Bu durumun sebebini besinlerin içeriğinden farklı yerde arayan bir görüşmeci, geçmiş sofra adabıyla bugünün farklılığından bahsetmektedir.

“...Çocukken bir tabaktan yerdik. Hepimiz oradan kaşıklardık. Ayrı tabaklarımı olmazdl. Ayrı ayrı yiyoruz şimdi. Yerde hep yiyorduk. Şimdi de yiyoruz. Ama o kalabalık yok. O sebeple daha fazla yiyoruz" (G8Kadın, 34).

Geçmiş anlatılarında, genç görüşmecilerin yetişkin görüşmecilere göre hastalık deneyimine daha yakın oldukları görülmektedir. Genç görüşmeciler ve yetişkin görüşmecilerin, geçmişteki sağlık tanımlamalarında besinlerin içeriği ön planda değildir. Besinlerin çeşitli kullanımı ve içeriğine önem verilmesi sadece maddi şartlar el verdiği için yapılmaktadır. Sofrada çeşitlilik, özellikle sağlıklı olmak adına seçilen bir davranış değildir. Ayrıca belirli besinlerin sağlıklı olduğu için tüketilmesi de söz konusu değildir. Bir anlamda besinlerle sağlik arasındaki ilişki besinlerin çok tüketilmesi ile alakalıdır. Besinlerin içeriği hakkında soru işaretleri olmadığından ne kadar çok yemek yenirse o kadar güçlü ve sağlıklı olunur fikri hakimdir.

\section{Sağlıklı Olmanın Günümüzdeki İfadesi}

Görüşmeler sırasında görüşmecilerin sağlık tanımlamalarını anlamak maksadıyla sorulan sorularda görüşmeciler, yaşadıkları rahatsızları ya da hastalıkları üzerinden bir tanımlamaya gitmişlerdir. Kilo konusunda yaşanan sorunlar, görüşmecilerin üzerinde yoğunlaştığı konulardan bir tanesidir. Kilo konusu sadece aşırı kilolu olmakla alakalı değildir aynı zamanda bireyin aktivitelerini gerçekleştirmesi, kendini dinç hissetmesi konularında da belirleyicidir.

"Akşama kadar masa başı iş yapıyorum oturuyorum. Sekiz kilo aldım. Bunun tek sebebi hareketsizlik” (G27- Kadın, 39).

Kilo problemi yaşamamasına rağmen kilosunun fazla olduğunu düşünen ve bundan rahatsızlık duyan genç görüşmeci, uzman görüşünü dikkate almadığını ve kendi başına kilo vermeye çalıştı̆̆ını ifade etmektedir.

Son birkaç yıldır kilo vermeye çalışıyorum. Geçen yıl diyetisyene gittim.

Kendisi bana kilo vermene gerek yok ki dedi. Ama ben kendimi bu kiloda rahatsı hissediyorum. Örneğin üzerime bir şey aldı̆̆ımda yakıştırmıyorum. Bu sebeple de kendi başıma kilo vermeye çalıştım (G2-Erkek, 27).

Söz konusu görüş, tüketim kültürünün bireyler üzerinde yarattığı estetik kaygıların bir sonucu olarak düşünülebilir. Ayrıca tüketim kültürüne hizmet eden bir diğer görüş ise bireyin, pahalı yiyecekler aldığında sağlıklı tükettiğini düşünmesidir.

"Pazardan doğal sebze ve meyveler almaya çalışıyorum. Sanki sağllklı olmama yardımcı gibi hissediyorum. Ama bunun için de bir domatese daha çok para veriyorum mesela" (G8-Kadın, 34).

Sağlıklı olayı psikoloji ile ilişkili gören görüşmeciler de söz konusudur. Bu görüşmeciler, sağlıklı olabilmek için psikolojinin iyi olması gerektiğini belirtmişlerdir. Erkek görüşmecilerde 
sıklıkla psikoloji ve sağl1k arasında ilişki kurulmuştur.

...Bazı adamlar oluyor mesela 50- 60 yaşında 30-35 gösteriyor, kafasına
bir şey takmıyor, mental açıdan rahat. Kendine bakıyor. Vücudu diri,
yediğine bakıyor. Maddi durumu da iyi ise yaşlanması geç oluyor.
Mesela maden işçileri dinç değiller, eziliyorlar. Sürekli yer altındalar.
Kömürün tozuyla falan 35 yaşındayken 60 yaşına geliyorlar. Zaten sinir
stres ona yetiyor. Vücudu kırışıyor. Her açıdan etkileniyor. Saçı başı
dökülüyor. Yaşam koşullarıyla alakalı aslında. Mesela yoğurt ömrü
uzatsaydı Silifkeliler 150 yaşına kadar yaşardı... (G1-Erkek, 26).

Bir görüşün sağlığa hizmet ettiğini düşünmek, bireyin dışında bir süreçten etkilenerek oluşturulabilmektedir. Featherstone $(2013,149)$ bireylerin sağlıklı olabilmelerinin yolunun kendilerine sunulduğunu, bu yolların belirli ve düzenlenmiş olduğunu belirtir. Bu yollar dahilindeki bilgi, tecrübe ve pratikler çerçevesinde bireysel çabalar önem kazanmıştır. Bireyler de kendilerine sunulan düzene uymaya çalışmaktadırlar. Bu açıdan bakıldığında görüşmecilerin sağlıklı olmayı tüketim toplumunda kendilerine dayatılan sağlık önerileri ile tanımladıkları görülmüştür.
...Örneğin çocuğumun öğünlerini yedirebildiğim zaman çocuğum să̆llk- lıdır. Yiyeceklerini istediğim şekilde ve sağllkl yiyecekler yedirdiğim zaman. Kendim için de bu geçerli. Çocuk var diye öğün zamanlarında yiyemiyorum. Ögün zamanlarımı geçiriyorum. Bazen gece geç saatte yiyip yatıyorum. Vaktinde ve sağllklı şeyler yersem sağllklı olduğumu düşünüyorum (G9- Kadın, 29).

Sonuç olarak günümüz sağlık tanımlarında görüşmecilerin, tüketim kültürüne hizmet ettikleri görülmektedir. Satın alma davranışının sağlıklı olma ile ilişkili olduğunu düşünen görüşmeciler, satın alamadıklarında psikolojilerinin etkilendiğini ve bunun da sağlıklarının bozulmasına neden olduğunu vurgulamışlardır.

\section{Sağlık ve Beslenmenin Neo liberal Politikalardan Etkilenmesi}

Neo liberal politikalar, günümüz dünyasının temelinde yatan fikri temsil etmektedir. Bu fikir, hayatının her alanının satın alınabilecek ya da satılabilecek bir duruma dönüştürülmesini temsil etmektedir. Bir anlamda neo liberal politikalar hayatın her alanının ekonomi tarafından yönetilmesi ve belirlenmesidir. Son yıllarda sağlığın en çok konuşulan konu olduğunu düşündüğümüzde neo liberal politikaların ekonomik belirleyiciliğinin bu alanda da kendisini gösterdiği söylenebilir.

Foucault $(2001,115)$ araçsal aklın, sosyal hayatın tüm alanlarına yayılmasını neoliberalizm fikriyle açıklamaya çalışır. Ona göre diğer tüm alanlara yayılan ekonomik belirleyiciliğin sebebi neoliberal politikalardır. Neoliberal politikalar, her alanda yatırımı kolaylaştırırken ve özendirirken bir yandan da devlet desteğini en alt seviyeye indirmektedir (Steger 2004, 65). Harvey (2007) bu duruma "yaratıcı ylkım olarak neoliberalizm" adını vermektedir. Devlet desteğinin geri plana atılarak her alanda ekonomik belirleyiciliğin olduğunun ve girişimin desteklediğinin pozitif olduğunun yayılması geri planındaki negatif etkiyi görmezden gelmemize neden olmaktadir.

Neo liberal politikaların sağlık üzerindeki etkisini okuduğumuzda öncelikle karşımıza teknoloji çıkmaktadır. Teknolojik uygulamaların sağlık ve beslenme alanına etkisi; hormonlu gıdalar, hazır ya da dondurulmuş gıdalar ile yemek pişirmeyi kolaylaştırdığı öne sürülen mutfak aletleri üzerinden okunabilir.

Görüşmeler sırasında hazır gıdalar hem genç hem de yetişkin görüşmeciler için sağlıksız 
olarak tanımlanmaktadır. Yetişkin bir görüşmeci; "Beklemiş. Soğutucuda kalmış şeyler sağlı̆ga zararlıdır" (G15-Erkek, 59) şeklinde hazır gıdanın sağlığa zararlı olduğunu belirtse de kolaylık sağlaması açısından tercih edildiği görülmüştür. "Hazır gıdaların kolaylık sağladiğını düşünüyorum. Genelde ballk tutmaya giderken hazır şeyler altyorum. Bir de torunlarım geldiğinde hazır şeyler alıyorum" (G33-Erkek, 54). Besinlerin içeriğine ilişkin "sağllksız", "GDO lu” "katkı maddeli" gibi ifadeler görüşmecilerde tedirginlik yaratsa da hazır gıda kullanımından kaçınmadıkları görülmektedir. Hazır gıdanın kolaylık sağladığını öne süren çalışan yetişkin çalışan kadın; "Evimde hazır çorbam bulunur. Eğer çorba yapmam gerekirse hemen onu yaparım zamanım kisıtlı olduğundan çorba pişirmeye vakit bulamam çoğunlukla” (G5-Kadın, 45). Sözleriyle hazır gıdaya ilişkin düşüncelerini belirtmiştir. Hazır gıdanın kolaylık sağladığı fikri, bireyin çalışıp çalışmamasıyla da ilgili değildir. Örneğin bir görüşmeci, eşinin ev hanımı olmasına rağmen hazır gıdaları tercih ettiğini belirtmiştir.

"Biz mesela evde turşu bittiği zaman hazır alıyoruz. Turşu kurduğumuzda bütün bir yıl yetecek turş̧uyu kuramadiğımız için doğal olarak hazır alıyoruz... Her market alışverişimizde mutlaka mantı alırız. Onu da evde ara ara yaparız ama eşim kim hamur açmakla uğraşacak dediği için kolayına kaçıyoruz” (G35-Erkek, 53).

Görüşmeciler, dışarıda yemek yemenin de hazır gıdayı tüketmek olduğunu belirtmişlerdir. “...Beslenme kesinlikle değişti. Hazır yiyecekler arttı, abur cuburlar arttı. Ben üniversiteye gelene kadar sufle nedir ya da Malaga nedir bilmiyordum. Ancak Üniversiteye gelince bunlart ögrendim. Sanki İspanyol'um Malaga'yı nereden bileyim" (G1- Erkek, 26). Şeklinde görüşlerini aktaran görüşmecinin görüşlerinden de anlaşılacağı gibi hazır gıda ile dışarıda yemek yeme kültürü iç içe geçmiştir. Ayrıca dışarıda yemek yeme davranışı, birçok görüşmecinin düşüncelerinde hamburger yemek şeklinde cevaplanmıştır.

“...Mesela ben çocuğuma hamburger yedirmiyorum. Ama kizım okuldan çıktıktan sonra arkadaşlarına uyum sağlamak için yiyor. Ama sürekli değil ayda yllda bir kere. Sürekli sürekli yemiyoruz. Biz mesela ailecek yemeğe gittiğimizde o tarz yerlere gitmiyoruz. Sağllklı değiller. Iç̧indeki şeyler bağımlılık yapıyormuş ya ondan dolayı istemiyorum" (G7-Kadın, 35) .

Görüşmecilerin hazır gıdalardan kaçınma davranışı, sağlı̆̆ını korumak adına yaptığı bireysel bir davranış tarzı olarak düşünülebilir. Görüşmeler sırasında görüşmecilerin, sağlık sorunlarını bireyselleştirdikleri görülmüştür.

"Sağlı̆̆ımdan ben sorumluyum. Mesela tesadüfen karşıma gazetede bir yazı çıkınca "acaba bende bu hastalık var mı" diye merak edip okuyorum. $\mathrm{Bu}$ da hasta olma ya da ya hastaysam korkusuyla psikolojik olarak bağlantıll. Merak yani. Önceden bilgiye ulaşmak zormuş. Herkes istediği bilgiye ulaşabiliyor şimdi. Etrafinda bu kadar çok uyarıcıya maruz kalman da seni meraka sürüklüyor. Her aklına geleni araştırlyorsun. Mesela Google'da erkekler hamile kalır mi diye araştırmışlar. Aslında o da biliyor hamile kalamayacağııı ama yine de araştırıyor" (G2-Erkek, 27).

Bilgiye ulaşmanın kolaylığı, bilginin yayılması hızındaki artış ve her konuda bireylerin bilgi sahibi olabileceği şekilde detaylandırılan kaynaklar, görüşmecilerin, sağlık bilgisine ulaşmasında da dikkati çekmektedir. Görüşmeciler, sağlık bilgisine ulaşmak için; aile, sosyal çevre, televizyon ve interneti kullanmaktadırlar. Aynı zamanda iletişim kanallarından gelen reklam içerikli mesajlara da açık haldedirler. 
“Çörekotunu, televizyondan görüp aldım. Daha doğrusu televizyonda bas bas bağırıyordu yararlıdır, zaylflatır diye. Ben de bir aktar vardı sordum zayıflatır, iştahı kapatır dedi" (G4-Erkek, 46).

Bireyler, kendi sağlıklarından kendileri sorumlu olduklarından hem medyadaki hem de sağlık kurumlarındaki birçok sağlık uzmanını takip etmektedirler ama bu takip sürecinde doktorlara karşı kafalarında soru işaretleri söz konusudur.

"Ben onu çok dinlemiyorum ama söyledikleri de mantıksız gelmiyor yani. Mesela birinci düşmanımız şeker diyor ya ben buna inanıyorum. Mesela çaya bir keresinde tereyağı katın demiş. Bak bu mantıksız. Bu olacak bir şey değil ama şekere düşman demesi kanseri tetiklemesi bunlar mantıklı geliyor. Margarin yerine tereyağı yiyin demesi de mantıklı. Çok boş konuştuğunu düşünmüyorum açıçası. Canan Karatay mesela eskilerin yaptı̆̆ şeyleri tavsiye ediyor. Ama mesela bir tereyă̆ı çaya katmak ne kadar mantıklı o da tartışılır" (G7-Kadın, 35).

Uzmanların görüşlerine karşı kafasında soru işareti oluşan bir görüşmeci, "Uzmanlar kafa karıştırıyorlar. Bizim geleneksel yiyeceklerimiz bize yetermiş. Benim babaannem tek çeşit beslenir. Buradan bırak kilometrelerce yürür. Doktorlar şöhret için kendi isimleri klinikleri için bunları yapıyorlar" (G13-Kadın, 28).

İfadesiyle uzmanların, kar elde etme amacının halk tarafından olumsuz karşılandığını belirtmektedir. Uzmanların kar elde etme amacı, başka bir görüşmecinin ifadelerinde "Denize düşen yılana sarılır" (G2- Erkek, 27) sözleriyle ortaya çıkmıştır. Söz konusu ifadede uzmanı "yılan" gibi görmenin sebebi, uzmanın kar elde etme amacıyla toplumu yanlış yönlendirmesidir.

"En az üç doktora gidiyoruz zaten. Aynı düşünceleri olduklarında onları uyguluyorum. Eskiden daha güveniyorduk. Doktorlar insanlarl muayene ediyordu. Eliyle dokunuyordu sana. Neyin var deyip dinliyor yazlyordu. Geçen gün doktora gittiğimde yüzüme bile bakmadl. Elinde telefonla otuyordu. Bana bakmiyor telefona baklyor. Bana ultrason verdi. Ama onların da zararlı olduğunu biliyoruz. Yüzüme bakmadan beni ona gönderdi. Belki muayene etse gerek bile yok diyecek. Döndüm bir ay sonra çekildim götürdüm sonuçlarımı doktor yine aynı pozisyonda. Sanki hiç değişmemiş" (G15-Erkek, 59).

Neo liberal politikalar, her alanda ekonominin belirleyiciliğini temsil ederken bu durum sağlık alanında da kendini göstermiştir. Özellikle uzmanlara bakış açısı ve uzmanların sunduğu sağlık bilgisine yaklaşımda, soru işaretleri olduğu görülmüştür. Söz konusu endişenin sebebi ise bireylerin uzmanlara ilişkin güven duymamalarından ileri gelmektedir. Artan bireyselleşme, bireyleri hem sağlıklarından sorumlu tutup hem de bu konudaki bilgilerini taze tutmaya itmiştir. Örneğin hazır gida endüstrisinin sağlıksız olarak nitelendirilmesine rağmen tercih edilmesi, hazır gıdaların bireylere sunduğu tüketim fikriyle alakalı olarak düşünülmektedir. $\mathrm{Bu}$ alanda tüketim kültürünün etkisi, bireyleri hem sorgulamaya itmekte hem de tüketmeye devam ettirmektedir.

\section{Korku ile Risk Kültürünün Beslenme ve Sağlık İlişsisinde Okunması}

İnsan sağllğı için riskli olarak düşünülen besinlerin, görüşmeciler tarafından korku ile karşılandığı söylenebilir. Örneğin hazır gıdalar, GDO'lar ve hormonlu yiyecekler, sağlık için risk taş1yan unsurlar olarak dikkati çekmektedir. Görüşmecilerin de bu tür besinlere korku ile yaklaşması, ürünü tüketmekten uzak durması ya da sınırlı bir şekilde ürünü tüketmesi şeklinde kendini 
göstermektedir.

Sağlığını korumak adına beslenmeye dikkat edilmesi gerektiğini çünkü bazı besinlerin, sağlık için riskler taşıdığını öne süren bir görüşmeci; "Beslenme özellikle de hormonlu gıdaların ve GDO ların kız çocuklarının erken ergenliğe girmesine neden olduğunu duymuştum. Açıkçası bu önemli bir durum” (G47-Kadın, 25). If fadeleriyle risk kültürüne ilişkin fikir vermektedir. Buna göre risk kültürü, hem neden hem de sonuçlar hakkındaki belirsizlikler olarak tanımlanabilmektedir.

\section{"Genel olarak böyle bilindiği için zararlı dedikleri için hormonlu gıdalardan kaçınmaya çalışıyoruz” (G8-Kadın, 34).}

Görüşmeler, risk kültürünün oluşma sebebinin, üretim sürecinden uzaklaşarak ürettiğine yabancılaşmak olup olmadığının sorgulanmasına izin vermiştir. Böylelikle üretim sürecinde yer alan ve hala daha üretim yapan görüşmeciler ile üretim sürecinde yer almayan görüşmecilerin risk konusunda fikirleri karşılaştırılabilmiştir. Görüşmeciler, ürettiklerinin tümünün GDO’lu olduğunu belirtmişlerdir.

"GDO lu tohumu ektiğinde ilk ylllar verim alamiyorsun. Sonrasinda ise çok iyi veriyor. Ama ben GDO ektikten sonra bir daha kendi tohumumu ekemiyorum. Her sene onu alıp ekmem gerek. Toprak kabul etmiyor kendi tohumumuzu" (G34- Erkek, 34 ).

Üretim sürecinden uzaklaşmış kent merkezinde yaşayan görüşmeciler ise üretim yapmayanlara göre hala piyasada hormonsuz ürünlerin olabileceğini ve bu ürünlere fazla para ödeyerek sahip olunabileceğini düşünmektedirler. Burada sağlığın satın alınabilecek bir durum olduğu ve metalaşması söz konusudur.

“...Mevsimsiz almayın diyorlar mesela. Ben de almamaya çalışlyorum. Ĕger alırsam da paraya klylyorum. Zaten para ile kalitesi belli oluyor. Ucuz domatesin hormonlu olduğu belli oluyor. Seralarda yetişen domates daha mantıklı gibi duruyor" (G7-Kadın, 35).

Görüşmeler sırasında görüşmecilerin, beslenme ile sağlıklarını etkileyeceklerine ilişkin hastalık korkusuna sahip oldukları görülmüştür. Örneğin bir görüşmeci, hormonlu gıdaların kendisinde gelecek korkusu yarattığına değinmektedir.

"Biz küçükken çoğu şeyi yerdik. Annem tavuk pişirirdi mesela. Şimdi tavuk pişirmekten korkuyoruz hormonlu ve să̆lıksız diyorlar. Zamanla bu sağllksız şeyler artacak ve yiyecek hiçbir şeyimiz kalmadığında bize ne satacaklar çok merak ediyorum. Sonuçta hormonlu tavuğu bilerek yaptyorlar" (G21-Kadın, 29).

Yine yediklerinin kendisinde kilo yapacağını ve şişmanlama korkusu taşıdığını söyleyen bir görüşmeci ise "Beslenirken kilo almaktan korkuyorum. Kendimi yemek yerken frenleyemiyorum ama yedikçe kilo aldiğımı hissetsem o kadar yemem... Yiyince pişman oluyorum çünkü rahat edemiyorum. Şişmanlayacağım yine. Ama durduramıyorum kendimi..." (G3-Erkek, 26). Şeklinde kendini kontrol edemediğini ve sürekli şişmanlama korkusu içerisinde olduğunu belirtmiştir.

Şişmanlıktan dolayı ötekileştirileceğine ilişkin korku taşıyan bir görüşmeci, "Gençken hep kiloluydum ve arkadaşlarım tarafindan alay konusu oluyordum. Bu durum beni çok rahatsız ediyordu. Şimdi aynı duruma düşmek istemiyorum..." (G24-Kadın, 50) sözleriyle, şişmanlığın bir sonucu olarak ortaya çıkan ötekileştirilme korkusunu anlatmaktadır. Söz konusu korkuların tümü, sonradan öğrenilmiş yapay korkular olması ile dikkat çekicidir. 


\section{Sonuç}

Foucault (1993, 269-271), gücün etkisini anlatırken somut bir şekilde sosyal hayatta yer almadığından bahseder. Güç, başarılı bir şekilde her şeyin arasına sızmıştır. Birey için korkular yaratılır ve bu korku dolu ortamda birey, bireysel başarısızlıkları ile mücadele eder durumdadır. Bu çalışmada ise birey, sağlıklı olmayı beslenme üzerinden gerçekleştirirken bazı risklerle ve korkularla karşılaşmaktadır. Riskler, gönüllü ve gönülsüz riskler olarak değerlendirilebilir (Sülün \& Sülün 2006, 120). Yani birey, sigara içmek gibi riski gönüllü bir şekilde sosyal hayatına dahil edebilir, ayrıca GDO'ların riskli olduğunu bilen bir kişinin, GDO'lu ürünleri kullanması, gönüllü bir şekilde riski tercih ettiğini ve sonuçlarından sorumlu olduğunu göstermektedir. Bir anlamda "riskli olanı seçme ve ondan uzak dur" ifadesi taşıan bu durum, iktidarın, bireyler üzerinde yarattı̆g kontrol mekanizmasına örnek olarak gösterilebilir.

Korkular ise bireyin sosyal hayatına eşlik eden bir hal almıştır. Örnek vermek gerekirse ölüm, doğal bir süreç iken bireylerin korktuğu ve kaçınmaları gereken bir alan izlenimi vermektedir. Birey, kendini ölüme yaklaştıracak durumlardan kaçınmalıdır. Bunun için de yaşlılığı geciktirici besinlere yönelmesi söz konusu olabilmektedir. Birey, yaşlanmasını geciktirecek uygulamaları seçecektir. Söz konusu süreç tam anlamıyla tüketim kültürüyle bağlantılı bir süreçtir.

Birey, tüketim kültürünün parçası nasıl olabilir? En basitinden nasıl besleneceğini öğreneceği bir sürece girerek Illich (2011)'in de dediği gibi "kabiliyetsizleştirici uzmanlıklar çağı" fikrinin bir parçası olarak bunu gerçekleştirebilmektedir. Burada birey, varolduğu zamandan beri en iyi yaptığı şeyi, "beslenmeyi” öğrenmektedir. Çünkü beslenme ve besin maddeleri, onun bilmediği yeni bilgilerle ve risklerle doludur.

Özellikle son yıllarda ortaya çıkan GDO ve hormon konusu, besinlere ilişkin durumu daha belirsiz hale getirmiş ve beslenmeyi risk ve korku kültürüne hizmet eder hale getirmiştir. $\mathrm{O}$ halde tümüyle bu süreçten uzak kalmanın imkanı var mıdır? Aslında görüşmecilerin davranışları, onların hazır gıdanın ürünlerinden uzak durmak gibi bir davranışlarının olmadığını ortaya koymuştur. Hazır gıda, bireylere yenilik ve kolaylık sağlaması adına tercih edilebilmektedir. Ayrıca sonuçlarının da uzun vadede ortaya çıkacağına ve bu süreçte görüşmecilerin de yaşıyor olmayacaklarına ilişkin inançları söz konusudur. Bu noktada akıllara Bauman (2010)'ın ünlü tıraş bıçağı örneği gelmektedir. "Ne yapsaydık, çağın dışında mı kaysaydık" derken alaycı bir ifade ile tıraş bıçağının, tüketim kültürüne hizmetini anlatır. Kendisi de bu süreçte adım adım tüketim kültürüne, tıraş bıçağı vasıtasıyla bağlanmıştır.

Sağl1k konusundaki gelişmelerden görüşmecilerin birebir haberdar oldukları görülmektedir. Gerek sosyal medya gerek televizyon vasıtasıyla sağlık uzmanlarının besinlere ilişkin konuşmalarına ulaşabilmektedirler. Ancak uzmanlara karşı güvensiz oldukları görülmüştür. Bunun sebebi ise bir konu üzerinde birçok uzmanın anlaşamaması ve bir konuda birçok fikrin ortaya çıkmasıdır. Bu durum bireyleri korkuya sevk etmekte ve uzman tüketimine yöneltmektedir. Görüşmeciler, bir konuda karar verebilmenin en az iki doktora danışma ile söz konusu olabileceğini belirtirken sağliklı olma sürecinin ne kadar bireyselleştiği ve ne kadar tüketim kültürüne hizmet ettiği görülebilmektedir.

Son olarak modern dönem olgusu olan tek tipleştirici tüketici olgusunun çalışmada, esnekleştiği görülmektedir. Bir anlamda postmodern anlamların esnekliği, görüşmecileri kendi başlarına çare arar duruma getirirken bir konuda birden fazla görüş ve çözüm imkanı elde ettiklerini ortaya koymaktadır. Bu durum, görüşmeciler açısından olumlu sayılabilecek bir durum değildir çünkü bilgi konusundaki "anomi” durumu daha çok belirsizliğe ve dolayısıyla korkuya neden olmaktadır. Bu da sonuç olarak daha çok tüketim davranışı içerisinde bulunmaya neden olur. 


\section{KAYNAKÇA}

Akkor Y. E. (2013). Osmanlı Mutfağı. İstanbul 2013.

Arpacıoğlu Ö. \& Yıldırım M. (2011). "Dünyada ve Türkiye'de Yoksulluğun Analizi”. Niğde Üniversitesi İktisadi ve İdari Bilimler Fakültesi Dergisi 4/2 (2011) 60-76.

Aydın E. (1997). Deontoloji ve Tip Etiği Ders Notları. İstanbul 1997.

Baudrillard J. (2010). Tüketim Toplumu (4. b.). Çev. H. Deliceçaylı \& F. Keskin. İstanbul 2010.

Bauman Z. (2010). Sosyolojik Düşünmek. Çev. A. Yılmaz. İstanbul 2010.

Beck U. (2014). Risk Toplumu. Çev. A. Öz. İstanbul 2014.

Demirhan A. (1982). Klsa Tip Tarihi. Bursa 1982.

Duhm D. (2009). Kapitalizmde Korku. Çev. S. Şölçün. İstanbul 2009.

Evrensel.net. (2019, Ocak 10). Kaynak: https://www.evrensel.net/haber/51561/turkiyede-yetersiz-beslenme

Featherstone M. (2013). Postmodernizm ve Tüketim Kültürü. Çev. M. Küçük. İstanbul 2013.

Foucault M. (1993). Cinselliğin Tarihi Cilt 1. Çev. H. Tufan. İstanbul 1993.

Foucault M. (2001). Ders Özetleri. Çev. S. Hilav. İstanbul 2001.

Furedi F. (2014). Korku Kültürü. Çev. B. Yıldırım. İstanbul 2014.

Harvey D. (2007). “Neoliberalism As Creative Destruction”. The Annals Of The American Academy of Political and Social Science 610 (2007) 22-44.

Illich I. (2011). Tüketim Köleliği. Çev. M. Karaşahan. İstanbul 2011.

Karakuş-Umar E. (2019). Sağlığın Değişen Anlamı: Beslenme Üzerinden Bir İnceleme. Ankara 2019.

Koç M. (2013). Küresel Gıda Düzeni. İstanbul 2013.

Marcuse H. (1997). Tek Boyutlu İnsan: İleri İşleyim Toplumunun İdeolojisi Üzerine İncelemeler. Çev. A. Yardımlı. İstanbul 1997.

Niyaz Ö. C. \& İnan İ. H. (2016). “Türkiye'de Gıda Güvencesinin Mevcut Durumunun Değerlendirilmesi”. Adnan Menderes Üniversitesi Ziraat Fakültesi Dergisi 13/2 (2016) 1-7. Kaynak: http://dergipark.gov.tr/ download/article-file/277965

Onurlubaş E. \& Gürler Z. A. (2016). “Gıda Güvenliği Konusunda Tüketicilerin Bilinç Düzeyini Etkileyen Faktörler”. Gaziosmanpaşa Üniversitesi Ziraat Fakültesi Dergisi 33/1 (2016) 132-141.

Soydemir S. (2011). "Modernizmin Karanlık Yüzü: Risk Toplumu”. Sosyal ve Beşeri Bilimler Dergisi 3/2 (2011) 160-178. Kaynak: http://dergipark.ulakbim.gov.tr/sobiadsbd/article/viewFile-/5000136914/ 5000125849

Steger M. B. (2004). Küreselleşme. Çev. A. Ersoy. Ankara 2004.

Sülün Y. \& Sülün S. (2006). "İnsan ve Çevre". Eds. M. Aydoğdu \& K. Gezer, Çevre Bilimi (2006) 97124. Ankara.

Tunaboylu T. (1995). L'Humour et la Naissance de la Psychanalyse en Turquie. Yayımlanmamış Doktora Tezi. Üniversite Paris-Nord, Paris 1995. 